\title{
Renal effects of the new calcium channel blocking drug isradipine
}

\author{
B. K. Krämer ${ }^{1}$, M. Häussler ${ }^{1}$, K. M. Ress ${ }^{1}$, G. A. Müller ${ }^{1}$, K.J. Burger ${ }^{2}$, and T. Risler ${ }^{1}$ \\ ${ }^{1}$ Department of Internal Medicine III, Section of Nephroplogy and Hypertension, University of Tübingen, Tübingen, and \\ 2 Sandoz AG, Nürnberg, FRG
}

Received: February 19, 1990/Accepted: May 21, 1990

\begin{abstract}
Summary. The acute effect of a single oral dose of isradipine $5 \mathrm{mg}$ on blood pressure, renal haemodynamics, electrolyte excretion and plasma renin activity was studied in 10 healthy males.

Isradipine did not produce a significant change in systolic or diastolic blood pressure, and glomerular filtration rate, renal plasma flow, renal vascular resistance, and urinary albumin excretion remained constant. There was a marked natriuretic and diuretic effect about $1-3 \mathrm{~h}$ after isradipine. Plasma renin activity showed a slight, insignificant increase $1 \mathrm{~h}$ after dosing. Uric acid clearance and $\beta 2-$ microglobulin excretion showed no significant changes, despite an increase in sodium clearance, suggesting an additional mechanism of action other than the proximal tubular natriuretic effect of isradipine in normotensive volunteers.
\end{abstract}

Key words: Isradipine, renal function; calcium antagonist, healthy volunteers, side effects

Oral administration of the calcium channel-blocking drugs nifedipine, verapamil, diltiazem, nitrendipine, and nicardipine is known acutely to increase salt and water excretion, without affecting glomerular filtration rate (GFR) and renal plasma flow (RPF); diltiazem may increase GFR and RPF. These agents have no consistent effect on any of the measured components of the renin-angiotensin-aldosterone system (nifedipine may acutely increase plasma renin activity, PRA; [1]). However, no sustained effect of most of the calcium entry-blocking drugs on salt and water excretion has been demonstrated in patients [1].

Isradipine, a new dihydropyridine calcium antagonist, has been shown to be effective in the treatment of patients with hypertension or angina pectoris [2-4]. A smaller negative inotropic effect and less reflex tachycardia compared to nifedipine make isradipine a promising compound in the treatment of patients with coronary artery disease and congestive heart failure [5]. Krusell et al. [6] demonstrated an increase in GFR, RPF, sodium clearance, and lithium clearance, and a decrease in renal vascular resistance in essential hypertensive patients after 3.5 months of treatment with $17.5 \mathrm{mg} \cdot \mathrm{d}^{-1}$ isradipine. However, after 2 years of isradipine treatment
(13.3 $\left.\mathrm{mg} \cdot \mathrm{d}^{-1}\right)$ GFR and RPF were no longer significantly increased; data for lithium clearance and renal vascular resistance were not given [7]. Persson et al. [8] demonstrated an increase in RPF and no significant change in GFR or sodium excretion in hypertensive patients after 9 weeks on isradipine $\left(15 \mathrm{mg} \cdot \mathrm{d}^{-1}\right)$, whereas Rupoli et al. [9] demonstrated no change in GFR and PPF, but an increase in sodium excretion after acute administration of 2.5 to $7.5 \mathrm{mg}$ isradipine in essential hypertensives.

The aim of the present study was to evaluate the acute effects of isradipine on renal haemodynamics with special regard to sodium excretion, proximal tubular function and the renin-angiotensin-aldosterone system in normotensive subjects.

\section{Subjects and methods}

10 healthy, male, normotensive subjects [mean age 26 (4) y, mean weight $76(6) \mathrm{kg}$, mean height $182(3) \mathrm{cm}$ ] participated in the study after giving their informed consent. The protocol was approved by the local Ethical Committee. None was taking any other drug. They all received extensive dietary counseling in order to achieve a salt intake of about 120-140 $\mathrm{mmol} /$ day during the study periods.

After an overnight fast the subject was placed in the supine position, cannulae were inserted into antecubital veins on both sides and the subject drank $500 \mathrm{ml}$ water every $60 \mathrm{~min}$. Inulin clearance and PAH (para-aminohippurate) clearance were measured by the constant infusion technique after a loading dose at $08.30 \mathrm{~h} \mathrm{(120} \mathrm{mg} \mathrm{inu-}$ lin $\cdot \mathrm{min}^{-1} \cdot \mathrm{m}^{-2}$ and $40 \mathrm{mg} \mathrm{PAH} \cdot \mathrm{min}^{-1} \cdot \mathrm{m}^{-2}$ during $30 \mathrm{~min}$ as loading dose; $24.5 \mathrm{mg}$ inulin $\cdot \mathrm{min}^{-1} \cdot \mathrm{m}^{-2}$ and $14.6 \mathrm{mg} \mathrm{PAH} \cdot \mathrm{min}^{-1} \cdot \mathrm{m}^{-2}$ during $330 \mathrm{~min}$ as constant infusion). At $10.30 \mathrm{~h}$ the subject received either $5 \mathrm{mg}$ isradipine or placebo (the examination was repeated after 7 days with the other substance) in a crossover, double-blind fashion. Baseline renal haemodynamic and laboratory measurements were made during two 30 min periods from 09.30 to $10.30 \mathrm{~h}$ $(-1-0 \mathrm{~h}$ in Table 1$)$. Subjects voided spontaneously every $30 \mathrm{~min}$. PRA and plasma aldosterone concentration (PAC) were measured by commercially available kits (Renin MAIA, Fa. Serono Diagnostika GmbH, Freiburg, FRG; Coat-A-Count Aldosteron, Fa. H. Biermann Medizinische Systeme GmbH, Bad Nauheim, FRG). Serum and urinary potassium, sodium, calcium, creatinine, and uric acid were measured by routine laboratory methods. Plasma isradipine was measured by a radioimmunoassay. Systolic (SBP) and diastolic blood pressure (DBP) were measured every $30 \mathrm{~min}$ throughout the study with a sphygmomanometer.

Statistical evaluation was done by means of the paired t-test. Data are given as mean with (SEM). All clearances were normalized 
Table 1. Renal plasma flow (RPF), glomerular filtration rate (GFR), sodium clearance (CL ${ }_{\mathrm{Na}}$ ), urine volume excretion (UV), uric acid clearance $\left(\mathrm{CL}_{\mathrm{U}}\right.$ ), albumin excretion (UAE), and $\beta 2$-microglobulin excretion ( $\beta 2 \mathrm{ME}$ ) after oral administration of $5 \mathrm{mg}$ isradipine (I) or placebo (C)

\begin{tabular}{|c|c|c|c|c|c|c|}
\hline & & \multicolumn{5}{|c|}{ Time after drug administration $0 \mathrm{~h}$} \\
\hline & & $\overline{-1-0 h}$ & $0-1 \mathrm{~h}$ & $1-2 \mathrm{~h}$ & $2-3 \mathrm{~h}$ & $3-4 h$ \\
\hline $\mathrm{GFR}\left(\mathrm{ml} \cdot \mathrm{min}^{-1}\right)$ & $\begin{array}{l}\mathrm{I} \\
\mathrm{C}\end{array}$ & $\begin{array}{l}121(3) \\
108(13)\end{array}$ & $\begin{array}{r}86(6)^{a} \\
111(10)\end{array}$ & $\begin{array}{r}104(7) \\
94(10)\end{array}$ & $\begin{array}{r}89(5) \\
105(6)\end{array}$ & $\begin{array}{r}86(6) \\
100(8)\end{array}$ \\
\hline $\mathrm{RPF}\left(\mathrm{ml} \cdot \mathrm{min}^{-1}\right)$ & $\begin{array}{l}\mathrm{I} \\
\mathrm{C}\end{array}$ & $\begin{array}{l}684(55) \\
565(57)\end{array}$ & $\begin{array}{l}559(36) \\
620(67)\end{array}$ & $\begin{array}{l}644(49) \\
517(38)\end{array}$ & $\begin{array}{l}582(41) \\
560(40)\end{array}$ & $\begin{array}{l}548(29) \\
573(56)\end{array}$ \\
\hline $\mathrm{CL}_{\mathrm{Na}}\left(\mathrm{ml} \cdot \min ^{-1}\right)$ & $\begin{array}{l}\mathrm{I} \\
\mathrm{C}\end{array}$ & $\begin{array}{l}2.2(0.3) \\
1.9(0.2)\end{array}$ & $\begin{array}{l}2.7(0.5) \\
2.3(0.2)\end{array}$ & $\begin{array}{l}3.3(0.3)^{\mathrm{b}} \\
2.2(0.3)\end{array}$ & $\begin{array}{l}2.8(0.3)^{a} \\
2.2(0.2)\end{array}$ & $\begin{array}{l}2.4(0.2) \\
2.2(0.2)\end{array}$ \\
\hline $\mathrm{U}-\mathrm{V}\left(\mathrm{ml} \cdot \mathrm{min}^{-1}\right)$ & $\begin{array}{l}\mathrm{I} \\
\mathrm{C}\end{array}$ & $\begin{array}{l}13.2(1.0) \\
12.2(1.5)\end{array}$ & $\begin{array}{l}12.5(0.9) \\
13.3(1.5)\end{array}$ & $\begin{array}{l}14.0(1.1)^{\mathrm{a}} \\
10.6(1.3)^{2}\end{array}$ & $\begin{array}{l}11.2(1.1) \\
10.5(1.1)\end{array}$ & $\begin{array}{l}10.1(1.1) \\
11.0(1.5)\end{array}$ \\
\hline $\mathrm{CL}_{\mathrm{U}}\left(\mathrm{ml} \cdot \min ^{-1}\right)$ & $\begin{array}{l}\text { I } \\
\text { C }\end{array}$ & $\begin{array}{l}9.7(0.9) \\
8.7(0.8)\end{array}$ & $\begin{array}{l}7.5(0.9) \\
9.3(1.0)\end{array}$ & $\begin{array}{l}9.8(0.5) \\
8.6(0.9)\end{array}$ & $\begin{array}{l}8.1(0.5) \\
8.2(0.8)\end{array}$ & $\begin{array}{l}7.4(0.7) \\
8.1(0.8)\end{array}$ \\
\hline $\mathrm{UAE}\left(\mathrm{ug} \cdot \mathrm{min}^{-1}\right)$ & $\begin{array}{l}\text { I } \\
\text { C }\end{array}$ & $\begin{array}{l}16.6(3.8) \\
18.1(4.5)\end{array}$ & $\begin{array}{l}10.7(2.5) \\
14.5(2.9)\end{array}$ & $\begin{array}{l}12.0(2.5) \\
12.2(2.9)\end{array}$ & $\begin{array}{l}10.5(2.1) \\
11.9(2.6)\end{array}$ & $\begin{array}{l}10.3(2.2) \\
10.4(2.3)\end{array}$ \\
\hline
\end{tabular}

a $P<0.05$ in comparison to placebo; ${ }^{b} P<0.01$ in comparison to placebo

Table 2. Systolic blood pressure (SBP), diastolic blood pressure (DBP), heart rate (HR), plasma aldosterone concentration (PAC), and plasma renin activity (PRA) after oral administration of $5 \mathrm{mg}$ isradipine (I) or placebo (C)

\begin{tabular}{|c|c|c|c|c|c|c|}
\hline & & \multicolumn{5}{|c|}{ Time after drug administration at $0 \mathrm{~h}$} \\
\hline & & $0 \mathrm{~h}$ & $1 \mathrm{~h}$ & $2 \mathrm{~h}$ & $3 \mathrm{~h}$ & $4 \mathrm{~h}$ \\
\hline $\mathrm{SBP}(\mathrm{mm} \mathrm{Hg})$ & $\begin{array}{l}\mathrm{I} \\
\mathrm{C}\end{array}$ & $\begin{array}{l}126(4) \\
130(5)\end{array}$ & $\begin{array}{l}122(5) \\
127(4)\end{array}$ & $\begin{array}{l}126(4) \\
122(3)\end{array}$ & $\begin{array}{l}123(5) \\
122(3)\end{array}$ & $\begin{array}{l}127(4) \\
124(4)\end{array}$ \\
\hline $\mathrm{DBP}(\mathrm{mm} \mathrm{Hg})$ & $\begin{array}{l}\mathrm{I} \\
\mathrm{C}\end{array}$ & $\begin{array}{l}83(2) \\
84(3)\end{array}$ & $\begin{array}{l}77(2) \\
85(2)\end{array}$ & $\begin{array}{l}81(2) \\
80(2)\end{array}$ & $\begin{array}{l}79(3) \\
83(2)\end{array}$ & $\begin{array}{l}81(2) \\
83(3)\end{array}$ \\
\hline HR (beats. $\cdot \min ^{-1}$ ) & $\begin{array}{l}\mathrm{I} \\
\mathrm{C}\end{array}$ & $\begin{array}{l}67(3) \\
66(3)\end{array}$ & $\begin{array}{l}69(3) \\
67(3)\end{array}$ & $\begin{array}{l}68(3) \\
64(2)\end{array}$ & $\begin{array}{l}70(3) \\
65(2)\end{array}$ & $\begin{array}{l}68(3) \\
65(2)\end{array}$ \\
\hline $\mathrm{PAC}\left(\mathrm{pg} \cdot \mathrm{ml}^{-1}\right)$ & $\begin{array}{l}\mathrm{I} \\
\mathrm{C}\end{array}$ & $\begin{array}{l}78(6) \\
91(9)\end{array}$ & $\begin{array}{l}70(7) \\
77(12)\end{array}$ & $\begin{array}{l}70(8) \\
70(15)\end{array}$ & $\begin{array}{l}77(11) \\
74(12)\end{array}$ & $\begin{array}{l}71(8) \\
69(8)\end{array}$ \\
\hline $\begin{array}{l}\text { PRA AI } \\
\left(\mathrm{ng} \cdot \mathrm{ml}^{-1} \cdot \mathrm{h}^{-1}\right)\end{array}$ & $\begin{array}{l}\mathrm{I} \\
\mathrm{C}\end{array}$ & $\begin{array}{l}0.9(0.2) \\
1.0(0.3)\end{array}$ & $\begin{array}{l}1.4(0.3) \\
1.0(0.3)\end{array}$ & $\begin{array}{l}1.3(0.3) \\
1.4(0.3)\end{array}$ & $\begin{array}{l}1.2(0.3) \\
1.1(0.4)\end{array}$ & $\begin{array}{l}1.4(0.3) \\
1.5(0.5)\end{array}$ \\
\hline
\end{tabular}

${ }^{a} P<0.05$ in comparison to placebo

to $1.73 \mathrm{~m}^{2}$ body surface. Mean blood pressure was calculated as diastolic blood pressure plus one third of the pulse pressure. Inulin clearance and PAH clearance were taken as measures of GFR and RPF. Renal vascular resistance (RVR) was calculated as mean blood pressure/RBF and RBF as RPF/1-haematocrit. Filtration fraction (FF) was calculated as GFR/RPF.

\section{Results}

GFR, RPF, sodium and urate clearance, urine volume, and urinary excretion of albumin and $\beta$-2-microglobulin are displayed in Table 1. Urinary sodium clearance and urine volume were significantly higher after isradipine than placebo, whereas RPF, uric acid clearance and albumin and $\beta 2$-microglobulin excretion were not significantly different. GFR remained unchanged during the course of the study except for a transient decrease from $0-1 \mathrm{~h}$ after isradipine. Systolic and diastolic blood pressure, heart rate, PRA and PAC were not significantly changed by isradipine (Table 2). In addition, creatinine clearance, as another measure of GFR, as well as calcium and potassium clearance, filtration fraction and renal vascular resistance did not change during the course of our study.
Plasma isradipine levels $\left(\mathrm{ng} \cdot \mathrm{ml}^{-1}\right)$ were $2.08(0.66)$, $3.44(0.46), 3.02(0.44), 2.75(0.45), 2.13(0.32), 1.94(0.22)$, $1.75(0.14), 1.61(0.15)$ at $0.5,1.0,1.5,2.0,2.5,3.0,3.5,4.0 \mathrm{~h}$ after intake of $5 \mathrm{mg}$ isradipine.

Three subjects receiving isradipine complained of headache. No other side effects were reported.

\section{Discussion}

The oral administration of $5 \mathrm{mg}$ isradipine had no significant effect on blood pressure or heart rate in healthy, normotensive controls, whereas SBP and DBP were significantly howered by it in essential hypertensive patients [6-9], and heart rate was either unchanged $[7,8]$ or increased [6,9]. Lederballe Pedersen et al. [10] did not find a fall in blood pressure in normotensive controls after administration of nifedipine, despite a marked effect in hypertensive patients.

The plasma concentrations of isradipine here were in accordance with other results $[11,12]$, demonstrating absorption and stable plasma levels within $30 \mathrm{~min}$ of administration. 
The present results demonstrate an increase in sodium excretion 1 to $3 \mathrm{~h}$ after oral administration of $5 \mathrm{mg}$ isradipine in normotensive subjects, and an increase of urine volume after 1 to $2 \mathrm{~h}$. The results are in accordance with other studies, in which increases in sodium excretion $[6,7,9]$ and urine volume $[6,9]$ were seen in essential hypertensive patients, but they are not fully in agreement with reports in which increases in sodium excretion [8] and urine volume $[7,8]$ did not reach statistical significance.

GFR (except for a transient decrease in the first $h$ after drug intake), RPF, RVR and FF remained unchanged throughout the $5 \mathrm{~h}$ of observation in accordance with some findings in hypertensive patients (GFR [7-9], RPF $[7,9], \mathrm{FF}[6,7]$ ), but in contrast to others (increase of RPF [6, 8], GFR [6]; decrease of FF [8], RVR [6]). In hypertensive patients RVR was decreased and PRF was increased after $20 \mathrm{mg}$ nifedipine, whereas no effect was shown in normotensive patients [13]. In general, no consistent change in renal haemodynamics has been demonstrated after intake of dihydropyridine calcium antagonists [1].

Albumin excretion, a marker of glomerular permeability, was unchanged after isradipine, and so were uric acid clearance and $\beta 2$-microglobulin, markers of a proximal tubular effect. This does not support a dominant proximal tubular natriuretic effect, as the mechanism of the isradipine-induced natriuresis. In contrast to these results, Krusell et al. [6] and Pedersen et al. [7] demonstrated an increase in uric acid clearance in hypertensive patients after isradipine administration, suggesting a proximal tubular mechanism. In addition, the increase in lithium clearance [6] after isradipine treatment is thought to be a measure of increased proximal fluid output. Using the lithium clearance method, an increase in absolute distal reabsorption of sodium after isradipine intake has been shown [6], which was thought to be compensatory for proximal loss. It has been hypothesized that calcium entry blockers induce their diuretic and natriuretic effects via a direct action on both proximal and distal tubular segments $[1,14]$. The effect appears to be independent of any vascular action of the drugs [1], and the present results for isradipine are in accordance with that assumption.

PRA and PAC, as measures of a hormone system involved in regulation of intrarenal haemodynamics were unchanged (slight trend to increase in PRA at $1 \mathrm{~h}$ ) after isradipine intake. PRA in essential hypertensive patients was either increased $[8,9]$ or unchanged [3] and PAC was also unchanged [9]. There do not appear to be any reports about the renin-angiotensin system after isradipine administration to healthy controls.

The differences between the present results and reports in the literature can be explained in part by the subjects studied, namely normotensive healthy controls in comparison to essential hypertensive patients [6-9] with differences in renal haemodynamics, especially hormonal regulation (angiotensin II, norepinephrine) $[15,16]$, and by the dose and mode of administration of isradipine: $5 \mathrm{mg}$ acutely in comparison to $2 \cdot 8.75 \mathrm{mg}[6], 2 \cdot 6.65 \mathrm{mg} / \mathrm{d}$ [7],2.7.5 $\mathrm{mg}$ [8] chronically, and 2.5, 5, 7.5 $\mathrm{mg}$ acutely [9]. Renal function in the present study was continuously monitored over $5 \mathrm{~h}$ as compared to a single measurement about 2 to $3 \mathrm{~h}$ after drug intake on other reports [6-9].
Notwithstanding these differences, a common denominator for all these findings is that isradipine possesses natriuretic properties without compromising renal function, and thereby has promising properties as an antihypertensive agent.

Acknowledgement. We thank Dr. S. Borzak, Brigham and Women's Hospital, Boston, MA for helpful discussions in the preparation of this manuscript.

\section{References}

1. Bauer JH, Reams G (1987) Short- and long-term effects of calcium entry blockers on the kidney. Am J Cardiol 59: 66A-71A

2. Winer N, Thys-Jacobs S, Kumar R, Davidson WD, Grayson M, Harris C, Walker D, Itskovitz H, Gonasum L (1987) Evaluation of isradipine (PN 200-110) in mild to moderate hypertension. Clin Pharmacol Ther 42: 442-448

3. Nelson EB, Pool JL, Taylor AA (1986) Antihypertensive activity of isradipine in humans: A new dihydropyridine calcium channel antagonist. Clin Pharmacol Ther 40: 694-697

4. Handler CE, Rosenthal E, Tsagadopoulos D, Najm Y (1988) Comparison of isradipine and nifedipine in chronic stable angina. Int J Cardiol 18: 15-26

5. Mauser M, Voelker W, Ickrath O, Karsch KR (1989) Myocardial properties of the new dihydropyridine calcium antagonist is radipine compared to nifedipine with or without additional beta blockade in coronary artery disease. Am J Cardiol 63: 40-44

6. Krusell LR, Jespersen LT, Schmitz A, Thomsen K, Lederballe Pedersen O (1987) Repetitive natriuresis and blood pressure. Long-term calcium entry blockade with isradipine. Hypertension 10: 577-581

7. Lederballe Pederson O, Krusell LR, Sihm I, Jespersen LT, Thomsen K (1989) Long-term effects of isradipine on blood pressure and renal function. Am J Med 86 [Suppl 4A]: 15-18

8. Persson B, Andersson OK, Wysocki M, Hedner T, Aurell M (1989) Renal and hemodynamic effects of isradipine in essential hypertension. Am J Med 86 [Suppl 4A]: 60-64

9. Rupoli L, Fruscio M, Gradnik R, Chianca R, Leonetti G, Zanchetti A (1989) Cardiovascular and renal effects of single administration of three different doses of isradipine in hypertensive patients. Am J Med 86 [Suppl 4A]: 65-66

10. Lederballe Pedersen O, Christensen NJ, Ramsch KD (1980) Comparison of acute effects of nifedipine in normotensive and hypertensive man. J Cardiovasc Pharmacol 2: 357-366

11. Chellingsworth MC, Willis JV, Broadfoot Jack D, Kendall MJ (1988) Pharmacokinetics and pharmacodynamics of isradipine (PN 200-110) in young and elderly patients. Am J Med 84 [Suppl 3B]: $72-79$

12. Tse FLS, Jaffe JM (1987) Pharmacokinetics of PN 200-110 (isradipine), a new calcium antagonist, after oral administration in man. Eur J Clin Pharmacol 32: 361-365

13. Krusell LR, Christensen CK, Lederballe Pedersen O (1987) Acute natriuretic effect of nifedipine in hypertensive patients and normotensive controls - a proximal tubular effect? Eur J Clin Pharmacol 32: 121-126

14. Leonetti G, Zanchetti A (1987) Effects of calcium antagonists on renal hemodynamics and water and sodium excretion in hypertensive patients. J Cardiovasc Pharmacol 10 [Suppl 5]: 93-97

15. De Leeuw PW, Birkenhäger WH (1987) Renal blood flow in essential hypertension. J Cardiovasc Pharmacol 10 [Suppl 5]: 10-13

16. Bauer JH, Reams GP (1989) Do calcium antagonists protect the human hypertensive kidney? Am J Hypertension 2: 173S-178S

Prof. Dr. T. Risler

Medizinische Klinik

Otfried-Müller-Straße 10

W-7400 Tübingen, FRG 